DE DE GRUYTER

OPEN

DOI 10.1515/pesd-2015-0011

PESD, VOL. 9, no. 1, 2015

\title{
THE ACTUAL STAGE OF POTENTIAL DEVELOPMENT REGARDING THE TOURISM IN SLĂNIC MOLDOVA RESORT, BACĂU COUNTY
}

\author{
Ovidiu Cristian Popa ${ }^{1}$
}

Key-words: Slanic Moldova, tourism, mountain, balneoclimatheric, mineral wather.

\begin{abstract}
This article illustrates the concept of tourism potential, which includes all natural and human tourism resources which generate various forms of tourism. Slănic Moldova town is in a great development, being sustained by the glorious oldtime image: "Moldova's Pearl". The recent accomplishments, the implementation projects and the short and medium time investment programs aim not only to affirm the resort at a regional level, but to transform it in to an authentic "Romanian tourism pearl”. Developing Slănic Moldova town will aim to develop its natural resources. For the years to come, it is willing to sustain a long-lasting economy especially based on touristic services at a European level, but also on diversifying the local economic activities, in respect for the nature and permanent environment preoccupation. In order to reach certain values the contribution of all factors that can determine the town's socio-economic development are needed: the local community and the local's support, keeping the environment intact and not the least increasing the number of tourists. Slănic Moldova will be one of the main touristic balneoclimatheric mountain destinations in Romania having a diverse and attractive touristic offer during the entire year, high quality touristic services, in an exceptional, pollution free, natural environment. Slănic Moldova will pass through an essential stage of its development, in which the national and external touristic context will be redefined. Being guided by the reputation of „Moldova's Pearl”, Slănic Moldova will develop its mineral waters and great natural environment extraordinary potential, thus becoming the great ,pearl of Romanian tourism”.
\end{abstract}

\footnotetext{
${ }^{1} \mathrm{PhD}$. Stud. University of Bucharest
} 


\section{The organizing and developing level regarding the technical-material base for tourism}

The tourism activity progress, in optimal conditions depends, besides the existence of a great touristic potential, on the existence of a solid technical-material base, which supports it; a technical-material base without which the touristic resources development would be precarious. The technical-material base for tourism comprises those elements which support the tourism, contributing to the improvement of the touristic act and satisfying the tourist's demands along their stay. In this way, we remark the touristic structures with accommodation function, the public alimentation structures, the treatment and recreation structures, the transportation structures of which the tourist benefit of at the consumption place, but also the promoting and touristic marketing structures, which have an important role when choosing the touristic destination.

An overview regarding the Slănic Moldova's touristic infrastructure reveals it's concentration on the left side of Slănic's river, in the resort itself and also in the rest of the territory. It is especially remarked the large number of touristic structures with accommodation which also contain in most of the cases, public alimentation structures. The stand-alone touristic structures with accommodation function are few and occupy the central part of the resort, being integrated in the commercial area assembly. The treatment and recreation spaces have a greater range (sport fields, parks, the headwaters area), given the village's character - a spa resort - which occupies more than half of the resort's surface.

A negative aspect regarding the arrangement and the touristic equipment of the space is given by the presence of some large non-arranged, insalubrious spaces, located close to the accommodation units, to which numerous disposed constructed spaces are added that affect the resort's general visual space. On the other hand, it must be remarked the presence of numerous units that are in course of renovation or construction which will complete the resort's tourism technical-material base.

\section{The accommodation structures}

2.1Theoretical notions. The accommodation units represent the principal elements which economically sustain the touristic activity, having the greatest weight regarding the incomes from tourism. Although they are not themselves the touristic attraction points, they represent the element without which the touristic activity would suffer, the touristic potential development being a precarious one without some accommodation structures which would offer the possibility of spending a longer time in the touristic areas.

According to the Statistics National Institute, the touristic reception structure with accommodation function represents any construction or arrangement that offers permanently or seasonally the accommodation service and other services 
specific for tourists. According to this Institute, in Romania can be mentioned as accommodation units the following ${ }^{2}$ : hotel, motel, hostel, hotel for the young, cabin, fishing and hunting cabin, cottage, bungalow, urban boarding house, rural boarding house, camping, school camps, vacation village, touristic unit resembling of a small cabin, touristic rest areas, accommodation spaces on maritime and fluvial ships.

In the specialized works, the touristic reception structures with accommodation function are diverse, according to the organization form, the property regime, the functionality period, being classified $\mathrm{in}^{3}$ : hotelier accommodation structures, extra-hotelier structures, (private property accommodation structures - vacation houses, apartments in immobile with coproperty, apartments with multi-property; rentable accommodation structures private houses accommodation, apartments rented by firms or companies without providing services, accommodation capacities in rural environment), as well as non-permanent accommodation structures (camping and caravanning).

Across time, in Romania, numerous acts and regulations were emitted which contain methodological norms regarding the touristic reception structures classification (OM 20/1995, HG 1328/2001, OM 510/2002, OM 636/2008, OM $1296 / 2010$, OM 1051/2011, Order 65/2013), for alignment to the norms applied in the European countries with an evolved tourism and taking into account the World's Tourism Organization's recommendations.

In accordance with the last methodological regulation, in Romania can function ${ }^{4}$ : hotels (5-1 stars), apartment-hotels (5-2 stars), motels (3-1 stars), hostels (3-1 stars), touristic cottages (5-1 stars), bungalows (3-1 stars), touristic cabins (3-1 stars), vacation villages ( 3 and 2 stars), camping, touristic rest areas, camping houses (4-1 stars), touristic boarding houses (5-1 daisies), apartments and rooms for rent (3-1 stars), reception structures with accommodation functions on floating pontoons, maritime and fluvial ships (5-1 stars).

2.2The total number of accommodation structures. A resort with a tradition starting from the inter-war period, Slănic Moldova has known a regression period after the Second World War, due to the accommodation base destructions. It started to be refurbished after 1950, when various cottages were repaired and new accommodation units were built, and especially in the ' $80 \mathrm{~s}$ when giant

${ }^{2}$ www.insse.ro

3 Gheorghilaş A.(2005), Geografia turismului internaţional, Publishing house Universitară, Bucharest, pag. 60-61.

${ }^{4}$ Order No. 65 / 2013 for the methodological norms approval regarding the issuance of touristic reception structures with accommodation and public alimentation functions certificates, licenses and tourism brevets. 
accommodation units were built, specific to the socialist period. For the period after 1990 a drop-down of the total number of accommodation units is observed, due to economic and politic changes, leading to the decrease of importance regarding tourism.

Although many accommodation units figure in the Trade Registry, according to the National Authority for Tourism website, from 1991, (the boarding houses Casa Alba, Izvoare, Maria and Rica villa), and other from the following years (25 units registered until 2007), the statistic data are yet short, thus the villages files show a continuous decrease of the total number of accommodation units until 2007, from 31 units in 1992 to 19 units in 1995, 11 in 2000 and only 6 accommodation units in 2007.

After 2007 a growth of the total accommodation units number is observed in Slănic Moldova, the village files indicating 15 accommodation units in 2013 (new accommodation units appear in this period, such as Cascada rest area, Eden Maison boarding house, Flora boarding house, Roua Florilor villa, Sara boarding house, a new body of Teleconstructia villa, and Coroana Moldovei hotel is re-opened, all these being registered in the Trade Registry after 2008). With all these, the National Authority for Tourism data show a higher number of reception structures with accommodation functions, fact observed also in the field researches, from which 20 accommodation units were identified only in Slănic Moldova resort, to which 16 units are added that are located along Nicolae Bălcescu street all the way to the Cerdac exit.

The field researches show that the reception structures with accommodation functions are concentrated in the central part of the touristic resort, which sums up more than half of the total number of accommodation units (approximately 55\%). The other part (approximately 45\%) is being distributed irregular especially along the main street, Nicolae Bălcescu (respectively DN12B), near Cerdac, but also on adjacent streets, where boarding houses and touristic villas have been developed in the past couple of years.

2.3The existent accommodation capacity. The existent touristic accommodation capacity (installed) represents the number of accommodation spots of touristic use registered in the latest reception document, homologation, classification of touristic accommodation units, exclusively the extra beds that can be added in case it is necessary. The accommodation spots pertaining to the touristic reception structures with touristic accommodation functions (houses, camping fields, etc) complementary to a basic touristic accommodation structure, (hotel, motel, camping, etc.) and their usage are comprised in the base structure. ${ }^{5}$

\footnotetext{
${ }^{5}$ According to http://statistici.insse.ro/shop/index.jsp?page=tempo3\&lang=ro\&ind=TUR102A
} 
In a village, the existent touristic accommodation capacity is calculated by summing up the data obtained from all the accommodation units in village. This way, the accommodation capacity is an indicator that shows the effective number of accommodation spots that the village has. The County Directorate for Statistics Bacău, indicates for the year 1973 a total number of 2208 accommodation spots distributed in A catergory villas (200 spots), I category villas (653 spots), II category villas (993 spots), III category villas (518 spots), hotels (171 spots), private houses (44) and camping (12 spots).

In the next period, when hotels specific to the socialist period are being built, the total number of accomodation spots increases, thus the resort had over 3200 accommodation spots at the end of 1980, a tendancy tipical to the mass tourism affirmation period.

After 1990 the situation changes, based on the economical and political changes, thus in 1992 the statistics indicated approximately 2800 accommodation spots, and in 1995 approximately 1700 accommodation spots were registered. The period after 1990 was generaly characterized by the touristic activity decrease, a part of the old accommodation spots being taken by other entities, such as „Banc Post” or "Romtelecom” which transformed them into national centers for advancing and accommodating their own employees. At the beginning of the year 2000 , the total number of accommodation spots decreases under 1000 (948 spots in 2000 and 932 in 2002), reaching only 694 in 2007. Nowadays, a rectification of this situation is encountered regarding the total number of accommodation spots, according to the National Authority for Tourism, the accommodation structures sums up a total of 1525 in 2013.

Although the greatest part of the accommodation capacity is concentrated in Slănic Moldova resort, numerous accommodation spots are spread along the main communication path, namely Nicolae Bălcescu Street.

2.4The accommodation capacity in function. The touristic accommodation capacity in function represents the number of accommodation spots for tourists offered by the touristic accommodation units, taking into account the number of days during which the units are open in the considerate period of time. It is expressed in spots-days. The spots from rooms or units that are temporarily closed due to lack of tourists, renovations or other reasons are excluded ${ }^{6}$.The accommodation capacity in function is a statistical indicator which mostly depends also on seasonality.

In Slănic Moldova resort, the available data indicates a close corelation between the increase of the number of spots in accommodation units and the

\footnotetext{
${ }^{6}$ According to http://statistici.insse.ro/shop/index.jsp?page=tempo3\&lang=ro\&ind=TUR103A
} 
increase of the number of spots-days, but especialely between the installed capacity and the unit's number of days in fuction. On one hand, an increase of number of spots-days is observed in the years when more accommodation spots are registerd, but on the other hand a function capacity dependency on the number of functioning days can be assumed. For the year 2002, the statistic data mention 295612 spotsdays, and it the next year of reference this number will decrease to 236668 spotsdays. In 2012, the dependancy between the capacity in function, the installed capacity and the number of functioning days is well highlighted, thus for over 1084 spots in installed capacity (more than in 2002) the capacity in function was inferior to the one from 2002 (290 748 spots-days in 2012 than 295612 in 2002), fact due to an average of 270 accomodation units functioning days this year. Nowadays, an accommodation capacity in function growth is observed, based on the growth of number of spots in accommodation units, and also on trying to reduce the seasonality, through adapting the accomodation units facilities for satisfying a variate category of tourists requests.

2.5The accomodation capacity based on the reception structures. The quality of the stay mostly depends not only on the accommodation base quantitative characteristics, respectively, on the existence of a certain number of spots which would satisfy a high demand, but also on its qualitative characteristics, understanding through this the types of accommodation units, the category of comfort, the renovation degree, etc.

In Slănic Moldova the accommodation capacity is concentrated, as we have previously shown, especially in the central area on the resort, but reception structures with accomodation function can be found spead out on the town's teritory, to the Cerdac exit, along the main artery, N. Bălcescu Street, but also on adjacent streets. Taking into account the touristic profile of the village, many of the actual accommodation structures have been designed from the beginning to accomplish this function, especially in units built in the socialist period, when great accommodation units have appeared (Hotel Euro Vacanța, Hotel Dobru, Hotel Venus), but also in the last 25 years, when numerous accommodation units such as touristic villas have appeared especially in less crowded areas of the resort.

Regarding the spots distribution on types of accommodation structures, in the entire village, $58 \%$ of these can be found in hotels, $23 \%$ in boarding houses, $17 \%$ in villas and $2 \%$ in touristic rest areas. At a territorial level though, there are major differences between the thermal baths area, where hotel units spots are predominant ( $77 \%$ of the total accommodation spots in the perimeter), especially built before 1990, while in the Eastern area of the town were developed especially touristic boarding houses types of units, which hold $89 \%$ of the total accommodation spots in this area. 
The situation is easy to explain if we take into consideration the period in which the accommodation units appeared and especially the context in which they appeared. In the thermal baths area, either hotel units, built during the socialist period, which had the purpose to serve the mass tourism that was on top in the 80s$90 \mathrm{~s}$, were generally predominant, either the villa type units, built especially in the period before the Second World War, as vacation houses in a famous spa area. The fact that some of these units are currently closed (Hotel Flora) or in a renovation process, thus being unable to receive customers, must be mentioned.

In the eastern side of the town, especially developed after 1990, the boarding house type units are predominant, usually organized as family business, which are added to the already existent accommodation base, diversifying the area's touristic offer.

Lately, the tourism consumer insists on the quality of the services and on the quality-price relation and less on the type of touristic accommodation unit. In this matter, the comfort level could have an essential part in taking the decision to choose a certain touristic unit. Slănic Moldova resort offers, from this point of view, solutions for every tourism consumers, disposing of accommodation units classified from 1 (Cascada rest area and Maria boarding house) to 5 starts (Siam Villa). In the entire resort, $40 \%$ of the total number of accommodation spots, are classified at 2 stars, while less than $1 \%$ of the accommodation spots are classified at 5 stars (respectively, those 15 spots from Siam Villa), and 10\% belong to the 4 stars category . Moreover, a percentage of $11 \%$ of the total accommodation spots are available in units which are presently in a renovation process or are closed, thus are not categorized. At a territorial level, in the thermal baths area the majority of accommodation spots are classified at 2 stars, which indicates the resort's basic function - treatment resort, dedicated to those who have different affections and generally to those who have low and medium incomes, tradition which was kept from the period before 1990, suggestive in this matter being hotel Venus, with almost 500 accommodation spots. On the other hand, approximately, $40 \%$ of the total accommodation spots are placed in units classified at 3 and 4 stars, generally in villa type units, with less than 100 spots (exception-Hotel Slănic și Hotel Euro Vacanța).

In the eastern part of the town, the higher percentage (54\%) is held by the accommodation unit spots classified at 3 stars, all of them being boarding houses type units, built in the period after 1990, having the purpose to offer tourists not only an accommodation spot during the treatment, but also a pleasant way to spend free time during the stay. $30 \%$ of the total accommodation spots, though, have an inferior level of comfort, being classified at 2, respectively, 1 star. In this area, there are also units with a high level of comfort, $16 \%$ of the total accommodation spots being classified at 4 stars (Cristal and Poiana Verde boarding houses). 
The units built before the Second World War and in the first years after, have a specific architecture, villa type, small heights, usually 3-5 stories and generally have a low number of spots available. From this category, we have Villa Teleconstrucția, Villa Pufu, Villa Palas, Villa Rica, Hotel Coroana Moldovei (under100 spots), Hotel Slănic (the only one that exceeds 100 spots). These have been built before the Second World War and right after the First World War and have suffered major damages during the wars. Although, they were mainly renovated starting 1960, keeping their initial architecture, they are placed in the 3 stars comfort category, excepting Coroana Moldovei Hotel, placed in the 4 stars comfort category.

\section{Public alimentation structures}

3.1. The public alimentation touristic structures quantitative characteristics. According to the official data, in Slănic Moldova resort, in 2013 there was a total of 24 public alimentation units, summing up to a total of 1680 table seats, either as a freestanding units, or as alimentation units integrated in the accommodation base. The realities from the filed show though a greater number of alimentation units, especially independent ones, the classic restaurants type, pizzerias and confectioneries. It is worth mentioning the fact that the data used in that analysis is based strictly on the official ones, registered in the statistics, the filed reality being slightly different from the official one. Many of the public alimentation units found on filed in the resort area weren't registered in the statistics. The is a possibility that some of the statistic information would not be identified in the field, especially in case of day bars integrated in the accommodation base, which most of the time were not registered. The statistic data show for the entire village, a total of 150 table seats $(9 \%$ of the statistic total) placed in one fast-food restaurant, although two pizzerias were identified on the filed which do not appear in the official statistic. Also, a number of 1330 table seats $(79 \%)$ can be found in the classical restaurants, independent or integrated in the accommodation units along the entire surface of the resort . Besides the ones from the resort itself, the classical restaurants can be found in boarding houses located close to the resort, most of the restaurants which were identified on the filed being registered also in the official statistic. A number of 200 table seats can be found in the day bars, also independent or integrated in the accommodation units. It is worth mentioning the fact that many day bars can be found in the official statistic, although they were not marked on the field, because they were integrated in large accommodation units. 


\section{Treatment and recreation touristic structures}

The balneary tratment base from Slănic-Moldova resort appeared and developed very much due to its existence in this area of mineral headwaters which helped developing the balneary tourism. The present natural cure factors are represented by the mineral headwaters which have a chemical composition and various concentrations, to which a kindly tonic-stimulant environment and the pure and clean air in the area are added.

In order to develop these natural factors in optimal conditions, the resort disposes of facilities for warm baths in tubs with mineral water, facilities for respiratory therapy (aerosols and inhalations), electrotherapy and hydrotherapy, pools for kinetotherapy, damps, facilities for certain peripheral vascular diseases and for medical gymnastics. Moreover, for patients with respiratory affections, at $18 \mathrm{~km}$ from the resort, at Târgu-Ocna there is an underground balneary sanitarium with a microclimate specific to a salt mine.

Along time and especially after 1990, the resort's base treatment has suffered numerous transformations. If before the Revolution there was a powerful treatment base on the right side of the Slănic river, which comprised the central base and the Racoviţă Central Pavilion area, nowadays the situation has changed. SlănicMoldova Balneary Sanatorium has the most important role from this point of view, in the resort and in the entire county. According to NIS, this unit is among the most important ones at a national level, along with Techirghiol balneary sanatorium and Mangalia balneary sanatorium. The unit has 40 beds and offers diverse medical recovery services in a hospital and ambulatory mode, specializing in the next pathological profiles: respiratory, hepato-digestive, renal, rheumatic- chronicdegenerative and circulatory.

Besides the treatment offered by Slănic-Moldova sanatorium, there are treatment bases in two other hotels in the resort Venus and Euro Vacanţa. Another treatment base existed in Flora Hotel, which is closed now, and the treatment base is conserved.

Venus Hotel treatment base has a surface of 452 square meters which assures a great number of procedures daily for treating digestive system, hepato-biliary, respiratory, metabolic and nutrition affections. In the electrotherapy section, ionization, diadynamic currents, ultrasounds, magnetodiaflux, short waves, inhalations procedures are made, and in the hydrotherapy section, bubble baths and galvanic baths and paraffin treatment procedures are made. Mineral water cures are made just under the recommendation of the specialized personnel. In Euro Vacanta hotel there is a modern treatment base with medical equipment that assures many types of procedures according to the affections and the specialist's recommendation. The therapies used here are: electrotherapy, respiratory therapy, massotherapy, thermotherapy and hydrotherapy. 
Besides these, a damp was founded in Slănic Moldova resort, which is used in treating cardio-vascular affections. The damp's usage level is yet high, a modernization being necessary in order to continue to offer qualitative services.

The recreation in the resort is firstly assured by the park located in the central area, used by tourists and also by the locals. Having a surface of 4,16 ha, the park has alleys, benches, rounds with flowers, a gazebo that completes the Casino's architectural style, busts of some famous Romanian writers (Ion Creangă, Ion Luca Caragiale, Mihai Eminescu), spring wells and playgrounds for children.

Near the central park, the recreation space is completed by the sport fields, respectively, a football and a tennis court, which respond, although not totally, to the population's need of active rest.

There are also other interest points for recreation: Cheşcheş glade with a camping, Cheşcheş glade, the cascade Slănic gap, the road of 300 stairs, Pufu river valley, Ignat peak, Cerbu peak, Şandru peak, Dobru peak, Pufu peak.

Reacently improved, the ski track completes the recreation infrastructure assambly in Slănic Moldova resort. Inaugurated on $6^{\text {th }}$ of March 2014, the ski track has a length of $1,5 \mathrm{~km}$ and a width of $38 \mathrm{~m}$, having a medium-easy difficulty. The track is located on the northern side of Nemira Mountains, behind the Cerdac Complex, at a height between $720 \mathrm{~m}$ (starting point) and $470 \mathrm{~m}$ (arriving point). The track has teleski, nocturne and facilities for producing artificial snow. By creating the track, reducing the touristic activities seasonality and attracting tourists in the cold season were aimed.

\section{Transportation structures}

The transportation infrastructure has an important role in the touristic activities. Through the accessibility level and the maintenance level favours or limits the tourist's access. Nowadays, the only way to access Slănic Moldova resort is DN12B, which assures the connection with Târgu Ocna and only from this point with the rest of the country. The access is thus limited, especially for tourists who do not have their own car, depending on the bus schedule. However, DN12B, which assures the connection between Târgu-Ocna and Slănic-Moldova, is in a general good state, accessible especially for tourists which have cars.

For tourists without cars, the resort has a large number of busses, which assures the connection between Târgu Ocna and Slănic Moldova, as well as busses between Slănic Moldova and Bacău.

Besides the national road DN12B, there is the county road DJ $116 \mathrm{~A}$, which begins at the town limit and continues through the mountains to Oituz village where it intercrosses with the national road DN11, which connects Bacău-Oneşti to Braşov, but the technical conditions of this road which could facilitate the 
connection with the rest of the country are precarious, the road being hardly accessible taking into account the fact that it is a forest road.

The possibility to reach Slănic Moldova on a rail road or on an air route is more difficult since the town does not have a rail road. Those who wish to travel by train being able to choose for this option only to the final point of the rail road, respectively to Saline halt in Târgu Ocna, from where they can travel to Slănic Moldova only by bus. By plain, one can travel to "George Enescu" International Airport, from where the journey can be continued by bus.

\section{References}

Băcănaru I., 1967, Consideraţii geografice privind tipologia aşezărilor rurale din România, Comunicări de Geografie, Vol. VIII., Iaşi.

Băcanu B., 2006, Practici de management strategic, Editura Polirom, Iaşi.

Cândea Melinda, Simon Tamara, 2006, Potențial turistic al României, Universității Publishing House in Bucharest.

Ciangă N., Dezsi Ş., 2007, Amenajarea turistică, Presa Universitară Clujeană Publishing House, Cluj - Napoca.

Ciangă N., 2002, Geografia turismului, Presa Universitară Clujeană Publishing House, Cluj-Napoca.

Erdeli G., Istrate I., 1995, Potențial turistic al României, Bucharest University Publishing House, Bucharest.

Erdeli G., Gheorghilaş A., 2006, Amenajări turistice, University Publishing House, Bucharest.

Gheorghilaş A., 2011, Geografia turismului. Metode de analiză în turism, University Publishing House, Bucharest.

Ielenicz M., Comănescu Laura, 2006, România - potenţial turistic, University Publishing House, Bucharest.

Negut S., 2003, Geografia Turismului, Meteor Press Publishing House, Bucharest.

Nicoară Y., Busnea R., 1981, Slănic Moldova - Mic îndreptar turistic, Sport-Turism Publishing House, Bucharest.

*** 1990 - 2012, Anuarul statistic al României, The National Comity for Statistics, Bucharest.

***2011, Slănic-Moldova's developing strategy during 2010-2020, Slănic Moldova's city hall. 